\title{
Biocontrol mechanisms of Trichoderma harzianum against soybean charcoal rot caused by Macrophomina phaseolina
}

\author{
Nima Khaledi*, Parissa Taheri
}

Department of Crop Protection, Faculty of Agriculture, Ferdowsi University of Mashhad, P.O. Box 91775-1163, Mashhad, Iran

Received: October 1, 2015

Accepted: January 26, 2016

\begin{abstract}
Throughout the world, charcoal rot, caused by Macrophomina phaseolina, is one of the most destructive and widespread diseases of crop plants such as soybean. In this study, the biological control capability of 11 Trichoderma spp. isolates against M. phaseolina was investigated using screening tests. Among all the tested Trichoderma spp. isolates, inhibition varied from 20.22 to $58.67 \%$ in dual culture tests. Dual culture, volatile and non-volatile tests revealed that two isolates of Trichoderma harzianum (including the isolates $\mathrm{T} 7$ and T14) best inhibited the growth of M. phaseolina in vitro. Therefore, these isolates were selected for biocontrol of M. phaseolina in vivo. The results of greenhouse experiments revealed that disease severity in the seed treatment with T. harzianum isolates was significantly lower than that of the soil treatment. In most of the cases, though, soil treatment with T. harzianum resulted in higher plant growth parameters, such as root and shoot weight. The effects of T. harzianum isolates on the activity of peroxidase enzyme and phenolic contents of the soybean root in the presence and absence of M. phaseolina were determined in greenhouse conditions. Our results suggested that a part of the inhibitory effect of $T$. harzianum isolates on soybean charcoal rot might be related to the indirect influence on M. phaseolina. Plant defense responses were activated as an elicitor in addition to the direct effect on the pathogen growth.
\end{abstract}

Key words: biocontrol, Macrophomina phaseolina, peroxidase, total phenol, Trichoderma harzianum

\section{Introduction}

Soybean (Glycine max L.) is one of the most important crops. It is a source of vegetable protein and oil (Herridge et al. 2008; Prévost et al. 2010). Soybean, though, suffers from various diseases. Soybean charcoal rot caused by Macrophomina phaseolina (Tassi) Goidanich is one of the most important diseases of soybean in tropical and subtropical regions of the world resulting in reduced yields and seed quality. In Iran, charcoal rot is an economically important disease of various oilseed plants in northern regions, especially in the provinces of Golestan and Mazandaran (Rayatpanah et al. 2011). Macrophomina phaseolina is a necrotrophic phytopathogen with a wide host range including more than 500 cultivated and wild plant species belonging to more than 75 families (Khan 2007; Salik 2007). Many of the species are economically important crops, such as corn, sorghum, bean, cotton, sesame, sunflower, melon, tobacco, and safflower, in addition to soybean (Su et al. 2001; Purkayastha et al. 2006; Singh et al. 2008). Although only one species is recognised within the genus Macrophomina, great variability in morphology and pathogenicity was recognised among isolates from different hosts (Fernandez et al. 2006). It mainly produces either microsclerotia or pycnidia. The fungus is not only soil-borne, but also seed-borne and infects plants from seedling stage to maturity (Purkayastha et al. 2006). Macrophomina phaseolina is considered a high-temperature pathogen. Disease severity increases as the air and soil temperatures increase from 28 to $35^{\circ} \mathrm{C}$, and when soil moisture is limited (Pearson et al. 1984; Gary et al. 1991). Under favorable conditions, the fungus causes many diseases like damping off, seedling blight, collar rot, stem rot, charcoal rot, and root rot, in various economically important crops (Babu et al. 2007). Estimates of yield losses due to charcoal rot in the United States were $2.5 \times 10,3.0 \times$ $\times 10,2.2 \times 10$ and $0.9 \times 10$ million metric tons in 2006, 2007, 2008, and 2009, respectively. This disease ranked in the top six of diseases among economically important soybean diseases in the United States from 2006-2009 (Koenning and Wrather 2010).

Charcoal root rot may be a difficult disease to control because of the nature of causal pathogen. Macrophomina phaseolina invades the roots of a host at an early stage, 1-2 weeks after planting, but the symptoms appear only in mature plants (Pearson et al. 1984). Efforts to control soybean charcoal rot by adjusting planting dates, crop rotation, planting densities, and irrigation have all been suggested as important ways of disease management (Bowen and Schapaugh 1989; Todd 1993). Host resistance may be a practicable method to manage this destructive disease. However, soybean genotypes with high levels of resistance have not been identified (Mengistu et al. 2007). Other management options are needed. Chemical fungicides are being replaced with biocontrol agents because of the emergence of fungicide-resistant fungal isolates and public concerns regarding the health and environ- 
mental impacts of these chemicals. During the past few decades, several potential biocontrol organisms have been isolated, characterised, and commercialised. Thus, biocontrol of plant diseases has received more consideration in disease management strategies (Shali et al. 2010).

Trichoderma spp. are considered as potential biocontrol agents and growth promoting fungi for many crop plants (Verma et al. 2007; Bai et al. 2008; Savazzini et al. 2009). The genus Trichoderma comprises a great number of fungal species. The antagonistic properties of these species are based on the activation of multiple mechanisms. Trichoderma spp. exert biocontrol activity against fungal phytopathogens either indirectly, by competing for nutrients and space, which modify mechanisms and antibiosis, or directly, by mechanisms such as mycoparasitism (Benitez et al. 2004). These biocontrol agents are effective against soil and/or seed borne fungal diseases of various plants (Kubicek et al. 2001). It is relatively easy for Trichoderma populations to be established in different types of soil and the populations can continue to persist at detectable levels for several months (Verma et al. 2007). Control of several soil borne fungal pathogens using Trichoderma harzianum has been reported by many investigators (Zeidan et al. 2005). Yet there is little information available on the use of T. viride (Kehri and Chandra 1991) and T. harzianum (Elad et al. 1986; Adekunle et al. 2001) as biocontrol agents against M. phaseolina in different plants. Aly and associates (2007) reviewed differential antagonism of Trichoderma sp. against M. phaseolina. The percentage of the melon plant in the commercial T. harzianum (Bi) + M. phaseolina treatment $(96.7 \%)$ was greater than that of M. phaseolina inoculation alone (46.7\%) and demonstrated the best results among various Trichoderma spp. in the control of melon charcoal stem rot (Etebarian 2006). Singh and associates (2004) suggested that cell surface hydrophobicity and the cell surface electrostatic charge of mycoparasitic Trichoderma spp. may contribute to non-specific adhesion onto the sclerotial surfaces of M. phaseolina that may be influenced by growth and environmental conditions. Studies of Sreedevi and associates (2011) revealed the antifungal activity of T. harzianum and T. viride isolates against $M$. phaseolina, the causal agent of groundnut root rot.

Induction of plant defense responses is believed to be one of the most important mechanisms for the biocontrol effects of Trichoderma spp. (Harman 2006). In addition to pre-formed physical and chemical barriers, plants have an inducible immune system. This system is capable of detecting motifs or domains with conserved structural traits typical of entire classes of microbes but not present in their host plants, namely the pathogen- or microbeassociated molecular patterns (PAMPs or MAMPs, respectively). MAMP-triggered plant defense responses are elicited rapidly and transiently. Early MAMP responses involve ion fluxes across the plasma membrane, the generation of reactive oxygen species (ROS), nitric oxide, various phytohormones, priming several defense-related genes, activation of corresponding proteins and also, but later, the deposition of callose and biosynthesis of antimicrobial compounds such as phenolics. Effective Trichoderma spp. isolates produce a variety of MAMPs which are the most widely described among plant-beneficial fungi so far (reviewed by Lorito et al. 2010; Hermosa et al. 2012). Various species of this powerful biocontrol agent induce cellular and molecular changes in plants that increase resistance to a variety of biotic and abiotic stresses (Brotman et al. 2013; Kumar 2013). The activity of defenserelated enzymes such as peroxidase, polyphenol oxidase, and phenylalanine ammonia lyase were reported to be significantly increased in greengram plants treated with a T. viride alone or in combination with Pseudomonas fluorescens as biocontrol agents of M. phaseolina (Thilagavathi et al. 2007). Treating the tomato plants with the use of $T$. arundinaceum resulted in priming the expression of defense-related genes belonging to the salicylic acid (SA) and jasmonic acid (JA) pathways against Botrytis cinerea and Rhizoctonia solani (Malmierca et al. 2012).

There are a few investigations on the biological control capability of T. harzianum against soybean charcoal rot (Taliei et al. 2012; Vasebi et al. 2013). So far, to our knowledge, there has not been any report on the involvement of priming plant defense responses by Trichoderma spp. as a mechanism of their biocontrol against M. phaseolina in soybean plants. Therefore, the objectives of the present investigation were (i) to screen and select effective Trichoderma spp. isolates against the soybean charcoal rot pathogen M. phaseolina, and (ii) to determine the role of selected Trichoderma spp. isolates, which were capable of controlling the pathogen in vitro, in activating soybean defense responses such as peroxidase activity and total phenolics as a part of mechanisms involved in Trichoderma-induced resistance in our pathosystem.

\section{Materials and Methods}

\section{Antagonistic and phytopathogenic fungal isolates}

Five isolates of T. harzianum and six T. viride isolates (obtained from the culture collection of plant pathology laboratory, Abureihan Campus, University of Tehran, Iran) were used in this study (Table 1). The phytopathogenic fungus, M. phaseolina, which was isolated from infested soybean Golestan Province, Iran, was also obtained from the same culture collection. All fungi were maintained on Potato Dextrose Agar (PDA) medium and sub-cultured monthly.

Table 1. List of Trichoderma spp. isolates used in this study

\begin{tabular}{lc}
\hline \multicolumn{1}{c}{ Genus and species } & Isolate \\
\hline Trichoderma harzianum & $\mathrm{T} 7$ \\
T. harzianum & $\mathrm{T} 8$ \\
T. harzianum & $\mathrm{T} 14$ \\
T. harzianum & $\mathrm{BI}$ \\
T. harzianum & $\mathrm{T} 5$ \\
Trichoderma viride & $\mathrm{T} 6$ \\
T. viride & $\mathrm{T} 10$ \\
T. viride & $\mathrm{T} 17$ \\
T. viride & $\mathrm{T} 20$ \\
T. viride & $\mathrm{T} 23$ \\
T. viride & $\mathrm{T} 24$ \\
\hline
\end{tabular}


Evaluation of antagonistic activity of Trichoderma spp. isolates on mycelial growth of Macrophomina phaseolina in vitro

\section{Dual culture technique}

All of the T. harzianum and T. viride isolates were screened individually against $M$. phaseolina by employing the dual culture technique described by Asran-Amal et al. (2010) with a few modifications. The Trichoderma spp. isolates and M. phaseolina were cultured, separately, on PDA medium for 7 days at $25 \pm 1^{\circ} \mathrm{C}$. Four-day old Trichoderma spp. cultures were inoculated on one side of a PDA plate and M. phaseolina cultures were inoculated at the opposite side of the Petri dish and the plates were incubated at $25 \pm 1^{\circ} \mathrm{C}$ for 6 days. The distance between discs was approximately $5 \mathrm{~cm}$. In the control treatment, a sterile agar disc ( $5 \mathrm{~mm}$ diameter) was placed in the dish instead of Trichoderma spp. isolates. There were four replicates for each treatment and the experiment was repeated three times. At the end of the incubation period, the radial growth of the pathogen was measured. The efficiency of Trichoderma spp. isolates to suppress radial growth was calculated as described by Asran-Amal et al. (2010) using the formula:

$$
L=\frac{C-T}{C} \times 100
$$

where: $L$ - inhibition of radial mycelial growth; $C$ - the radial growth measurement of the pathogen in the control; $T$ - the radial growth measurement of the pathogen in the presence of antagonists.

\section{Production of volatile metabolites}

Two selected T. harzianum isolates based on the mycelial growth inhibition assay against $M$. phaseolina were evaluated for the possibility of producing volatile inhibitory substances in vitro following the modified methods of Dennis and Webster (1971a). Briefly, a 5 mm diameter disc from the margin of the T. harzianum colony was placed in the centre of the Petri dishes containing PDA medium and each treatment had four replications. The Petri plates were sealed at the edges and incubated at $25 \pm 1^{\circ} \mathrm{C}$. After 5 days, M. phaseolina was inoculated on fresh PDA and the lids of the Petri plates inoculated with antagonist were replaced by M. phaseolina on PDA. The plates were fixed with cellophane-tape and incubated at $25 \pm 2{ }^{\circ} \mathrm{C}$. The control plates were only inoculated with $M$. phaseolina. The radial growth of $M$. phaseolina was recorded after 7 days of incubation. The percentage inhibition was calculated in relation to the control, by the above mentioned formula.

\section{Production of non-volatile metabolites}

The production of non-volatile substances by T. harzianum isolates against $M$. phaseolina was studied using the modified methods described by Dennis and Webster (1971b). The T. harzianum isolates were inoculated in $100 \mathrm{ml}$ sterilised Potato Dextrose Broth (PDB, Merck, Germany) in $250 \mathrm{ml}$ conical flasks, and incubated at $25 \pm 1^{\circ} \mathrm{C}$ on a rota- tory shaker set at $100 \mathrm{rpm}$ for 15 days. The control flasks were not inoculated with any of the antagonistic isolates. The culture was filtered through Whatman filter paper for removing mycelial mats. Then, the culture was sterilised by passing through a $0.2 \mu \mathrm{m}$ pore biological membrane filter. The filtrate was added to molten PDA medium (at $40 \pm 3^{\circ} \mathrm{C}$ ) to obtain a final concentration of $10 \%(\mathrm{v} / \mathrm{v})$. The PDA containing Petri dishes were inoculated with mycelial plugs ( $5 \mathrm{~mm}$ diameter) of M. phaseolina at the centres. The dishes were incubated at $25 \pm 2^{\circ} \mathrm{C}$ until the colony reached the plate edge. There were four replicates for each treatment and the experiment was repeated three times. Then, colony diameters and percentage inhibition were calculated in relation to the control by the above-mentioned formula.

\section{Preparation of Macrophomina phaseolina inoculum}

Inoculum preparation was carried out using the method described by Nerey et al. (2010) with a few modifications. Briefly, disks which were $5 \mathrm{~mm}$ in diameter were taken from a 4-day old colony of $M$. phaseolina grown on PDA at $25 \pm 1^{\circ} \mathrm{C}$, and placed into flasks containing millet grains, previously autoclaved at $121^{\circ} \mathrm{C}$ for $21 \mathrm{~min}$ on 2 successive days. The flasks were incubated for 10 days at $25 \pm 1^{\circ} \mathrm{C}$ in the dark and shaken every $2-3$ days.

\section{Greenhouse experiments}

Experiments were conducted using soil and seed treatments. The soil used in this experiment was a combination of clay, sand, and farmyard manure with the ratio of $1: 1: 1(\mathrm{v} / \mathrm{v})$. For treatments with autoclaved soil, the soil was autoclaved at $121^{\circ} \mathrm{C}$ for a minimum of $30 \mathrm{~min}$ at $100 \mathrm{kPa}$ (15 psi) on 2 successive days.

To obtain a conidial suspension of $T$. harzianum, the fungus was grown on PDA for 7 days at $25 \pm 2^{\circ} \mathrm{C}$. Conidia were harvested from the surface of the plates and washed in sterile distilled water and suspended in $0.05 \%$ tween 20. The fungal spore concentration was adjusted to $10^{5}$ spores $\cdot \mathrm{ml}^{-1}$. Seeds of soybean $\mathrm{cv}$. DPX were surface disinfected by soaking the seeds in $1 \%$ sodium hypochlorite for $3 \mathrm{~min}$, then rinsing the seeds three times in sterile distilled water. The seeds were soaked in $10 \mathrm{ml}$ of Trichoderma spore suspension (with a concentration of $10^{5}$ spores $\cdot \mathrm{ml}^{-1}$ ) and shaken using an electric shaker for $0.5 \mathrm{~h}$ at room temperature, then air dried in a laminar flow hood. For adhering the conidia to the seed surface, methyl cellulose was used. For methyl cellulose coatings, conidial suspensions were added (1/1) to $2 \%$ methyl cellulose.

For soil treatment, the surface-sterilised seeds were incubated for 3 days on a wet sterile filter paper in Petri dishes at $28 \pm 1^{\circ} \mathrm{C}$ on distilled water-soaked filter papers. Then, the seeds were each sown in $15 \mathrm{~cm}$-diameter plastic pots. Inoculation of soybean plants by the pathogen was carried out on the stem near the soil-line, using seven-day-old seedlings. Colonised millet grains were filled $1 \mathrm{~cm}$ above the soil surface, which contained $3 \mathrm{~g}$ of millet grain inoculums per pot. Sterilised millet grains which were placed on PDA without the fungus served as the control. Inoculated plants were grown at $28 \pm 1^{\circ} \mathrm{C}$ for 4 weeks in a greenhouse. In all of the cases in which 
lesions developed, the pathogen was re-isolated from the infected plants. Four replicate plants were inoculated in a completely randomised design and the experiment was repeated twice.

Five weeks after planting, the plants were removed from their pots and washed with running tap water. Then, disease severity was estimated using the disease scale (0 to 100) as described by Persson et al. (1997). Disease severity $(D S)$ was estimated using the formula:

$$
D S=\sum(X i N i) / N,
$$

where: $X$ - the disease grade $(0,5,10,25,50,75$, and 100), $\mathrm{Ni}$ - represented the number of diseased plants on the $i$-th grade of the disease scale, and $N$ - the total number of plants evaluated.

In addition, the average stem height and the wet and dry weights of soybean roots and shoots, were recorded 5 weeks after planting.

\section{Effect of Trichoderma harzianum isolates on phenolic accumulations and peroxidase (POX) activity}

For elucidating the mode of action of two T. harzianum isolates (T7 and T14) in vivo, we examined the phenolic accumulations and POX activity as part of the plant defense responses. The effect of treating the soybean seeds with $T$. harzianum isolates on the accumulation of total phenolics and POX activity, were evaluated using six treatments:

1. Treatment $\mathrm{H}$ - healthy plants;

2. Treatment $\mathrm{M}$ - plants treated with M. phaseolina;

3. Treatment T7 - plants treated with T. harzianum T7;

4. Treatment T14 - plants treated with T. harzianum T14;

5. Treatment MT7 - plants treated with T. harzianum T7 since infected with M. phaseolina;

6. Treatment MT14 - plants treated with T. harzianum T14 since infected with M. phaseolina.

In all the above mentioned treatments, the seeds were sown in autoclaved soil. Plants were carefully uprooted without causing any damage to root tissues. The uprooting was done at different time points $(0,1,2,3,4,5,6,7$, and 8 days after the pathogen inoculation). Three plants were sampled for each time point and these plants were kept separate for biochemical analysis. Fresh roots were washed in running tap water and homogenised with liquid nitrogen in a pre-chilled mortar and pestle. The homogenised root tissues were stored at $-80^{\circ} \mathrm{C}$ until used.

\section{Enzyme extraction and POX activity assay}

Root tissues collected from the plants were immediately homogenised with liquid nitrogen. One gram of powdered sample was transferred to $1 \mathrm{ml}$ of extraction buffer ( $0.1 \mathrm{M}$ sodium phosphate, $\mathrm{pH}$ 6.0). The extracts were centrifuged at $14,000 \mathrm{~g}$ for $20 \mathrm{~min}$ at $4^{\circ} \mathrm{C}$. The supernatant (enzyme extract) was transferred to a new tube and freeze at $-80^{\circ} \mathrm{C}$ until assayed. The protein concentration was determined as described by Bradford (1976) using bovine serum albumin (Sigma) as a standard. For determining
POX activity, enzyme extracts (containing $30 \mu \mathrm{g}$ of total protein) were added to $30 \mu \mathrm{l}$ of $200 \mathrm{mM}$ guaiacol and $25 \mathrm{mM}$ citrate phosphate ( $\mathrm{pH}$ 5.4). To each sample, $30 \mu \mathrm{l}$ of $30 \% \mathrm{H}_{2} \mathrm{O}_{2}$ was added. The absorbance was measured at $470 \mathrm{~nm}$ using a spectrophotometer. Enzyme activity was expressed as the change in the absorbance of the reaction mixture $\min ^{-1} \cdot \mathrm{g}^{-1}$ on a fresh weight basis.

\section{Quantification of phenolics accumulation}

The total phenolic contents of the methanol extracts were determined colorimetrically using Folin \& Ciocalteu's phenol reagent (Merck, Germany) as described by Seevers and Daly (1970). A standard curve was prepared using different concentrations of gallic acid. The results were expressed as $\mathrm{mg}$ gallic acid equivalent (GAE) $\cdot \mathrm{g}^{-1}$ fresh weight basis. Briefly, portions of $1 \mathrm{~g}$ of the root tissues were ground with a pestle and mortar in $16 \mathrm{ml}$ of $80 \%$ methanol for $10 \mathrm{~min}$ at $4^{\circ} \mathrm{C}$ in an $\mathrm{N}$-saturated atmosphere. The extract was filtered through cloth and centrifuged for $10 \mathrm{~min}$ at $4,000 \times \mathrm{g}$ and the liquid phase collected. The procedure was repeated three times. The pooled supernatants were evaporated at $40^{\circ} \mathrm{C}$ to a volume of $1-2 \mathrm{ml}$ and used for the analysis. Then, $0.5 \mathrm{ml}$ of the methanol extracts were dissolved in $7 \mathrm{ml}$ of distilled water and $0.5 \mathrm{ml}$ of Folin \& Ciocalteu's phenol reagent were added to them in a $10 \mathrm{ml}$ volumetric flask. The contents were mixed and allowed to stand for 5-8 min at room temperature. Next, one $\mathrm{ml}$ of a sodium carbonate solution $\left(75 \mathrm{~g} \cdot 1^{-1} ; \mathrm{Na}_{2} \mathrm{CO}_{3}\right)$ was added, followed by bringing the volume to $10 \mathrm{ml}$ with the addition of distilled water. Solutions were mixed and allowed to stand at room temperature for $1 \mathrm{~h}$ prior to the determination of total phenolic contents using a spectrophotometer at $725 \mathrm{~nm}$. The experiment was conducted in triplicates and repeated three times.

\section{Statistical analysis}

The greenhouse experiments were arranged as a factorial in a randomised complete block design with four replications. Statistical analysis of the data was carried out by analysis of variance (ANOVA) using SAS software (version 9.1). The means were separated using Tukey's multiple range tests at $p<0.05$, where the F-value was significant.

\section{Results}

\section{Effect of Trichoderma isolates on mycelial growth of Macrophomina phaseolina in vitro}

The comparison of the data obtained from the dual culture revealed that all 11 isolates of Trichoderma spp. inhibited the mycelial growth of M. phaseolina from $58.67 \%$ to $20.22 \%$. The highest level of inhibition belonged to T. harzianum T7 and the lowest level was observed for T. viride T24 (Table 2).

Two isolates of T. harzianum (T7 and T14), which showed the highest levels of inhibiting the pathogen growth in the dual culture test, were used for determining the capability of producing volatile and non-volatile 
Table 2. In vitro screening of Trichoderma spp. isolates against Macrophomina phaseolina by Dual culture test (7 days post inoculation)

\begin{tabular}{lcc}
\hline \multirow{2}{*}{ Isolates Trichoderma } & \multicolumn{2}{c}{ Dual culture } \\
\cline { 2 - 3 } & $\begin{array}{c}\text { mean radial } \\
\text { growth [mm] }\end{array}$ & inhibition $[\%]$ \\
\hline T. harzianum T7 & $18.6 \pm 0.3$ & $58.7 \mathrm{a}$ \\
T. harzianum T14 & $19.2 \pm 0.5$ & $57.3 \mathrm{a}$ \\
T. viride T20 & $21.7 \pm 0.1$ & $51.8 \mathrm{~b}$ \\
T. harzianum BI & $23.9 \pm 0.2$ & $46.9 \mathrm{c}$ \\
T. harzianum T8 & $25.9 \pm 0.2$ & $42.4 \mathrm{~d}$ \\
T. viride T17 & $28.3 \pm 0.3$ & $37.1 \mathrm{e}$ \\
T. viride T10 & $29.5 \pm 0.4$ & $34.4 \mathrm{ef}$ \\
T. viride T23 & $30.1 \pm 0.5$ & $33.1 \mathrm{f}$ \\
T. viride T6 & $33.5 \pm 0.0$ & $25.3 \mathrm{~g}$ \\
T. harzianum T5 & $35.9 \pm 0.2$ & $20.2 \mathrm{~h}$ \\
T. viride T24 & $35.9 \pm 0.2$ & $20.2 \mathrm{~h}$ \\
Control & $45.0 \pm 0.1$ & $0 \mathrm{i}$ \\
\hline
\end{tabular}

Four replicates were used for each treatment and the experiment was repeated three times.

athe means with the same letter do not have significant difference according to Tukey's multiple range test at $p<0.05$

metabolites. The results indicated that T. harzianum isolates apparently produced volatile and non-volatile substances that suppressed the pathogen growth. Data presented in table 3 clearly indicate that T. harzianum-T7derived volatile substances caused maximum inhibition of the mycelial growth of M. phaseolina. Mycelial growth of M. phaseolina was reduced to $56.72 \%$ and $49.52 \%$ by volatile metabolites of T. harzianum T7 and T14 isolates, respectively. A significant difference was not observed among the two T. harzianum isolates tested for the effect of non-volatile metabolites against M. phaseolina (Table 3).

\section{Effect of Trichoderma harzianum isolates on plant growth parameters and T. harzianum isolates' control of soybean charcoal rot in the greenhouse}

The results of greenhouse experiments showed that charcoal rot of soybean was significantly reduced by two T. harzianum isolates (T7 and T14) tested in both the autoclaved and non-autoclaved soils (Table 4). Average stem height, fresh and dry weights of the roots and shoots in the treatment in which the soil or soybean seeds were inoculated with T. harzianum isolates, were greater than those of the controls (Table 5). So, these isolates were effective in promoting plant growth parameters. Macrophomina phaseolina was isolated from all inoculated plants showing symptoms with different disease-severity levels. In most of the treatments investigated, the isolate T7 was more effective in promoting plant growth and reducing charcoal rot compared to isolate T14. Seed treatment with T. harzianum isolates promoted plant growth. But in most of the treatments, the amount of this promotion was less than that of the soil treatment with these isolates. Whereas, significantly more reduction of disease severity was observed by seed treatment with T. harzianum isolates in both autoclaved and non-autoclaved soils (Table 5).

Table 3. Effect of volatile metabolites and non-volatile metabolites of Trichoderma harzianum isolates on mycelial growth of Macrophomina phaseolina

\begin{tabular}{|c|c|c|c|c|}
\hline \multirow{2}{*}{ Isolates of T. harzianum } & \multicolumn{2}{|c|}{ Non-volatile metabolites } & \multicolumn{2}{|c|}{ Volatile metabolites } \\
\hline & colony area $\left[\mathrm{mm}^{2}\right]$ & inhibition $^{\mathrm{a}}[\%]$ & colony area $\left[\mathrm{mm}^{2}\right]$ & inhibition $^{\mathrm{a}}[\%]$ \\
\hline $\mathrm{T} 7$ & $615.4 \pm 34.1$ & $87.7 \mathrm{a}$ & $1,962.5 \pm 30.8$ & $56.7 \mathrm{a}$ \\
\hline $\mathrm{T} 14$ & $706.5 \pm 32.7$ & 85.9 a & $2,289.1 \pm 6.9$ & $49.5 \mathrm{~b}$ \\
\hline Control & $5024 \pm 39.8$ & $0 \mathrm{~b}$ & $4,534.2 \pm 19.5$ & $0 \mathrm{c}$ \\
\hline
\end{tabular}

Each treatment was replicated four times and the experiment was repeated three times with similar results.

athe means with the same letter do not have significant difference according to Tukey's multiple range test at $\mathrm{p}<0.05$

Table 4. Mean square of combined ANOVA on disease severity and several growth parameters of plants for biological-control treatments against Macrophomina phaseolina

\begin{tabular}{|c|c|c|c|c|c|c|c|}
\hline \multirow[t]{2}{*}{ Source of variation } & \multirow[t]{2}{*}{ df } & \multirow{2}{*}{$\begin{array}{l}\text { Stem height } \\
{[\mathrm{cm}]}\end{array}$} & \multicolumn{2}{|c|}{$\begin{array}{l}\text { Roots weight } \\
{\left[\mathrm{g} \cdot \text { plant }^{-1}\right]}\end{array}$} & \multicolumn{2}{|c|}{$\begin{array}{c}\text { Shoots weight } \\
{\left[\mathrm{g} \cdot \text { plant }^{-1}\right]}\end{array}$} & \multirow{2}{*}{$\begin{array}{l}\text { Disease } \\
\text { severity }\end{array}$} \\
\hline & & & fresh & dry & fresh & dry & \\
\hline Experiment (E) & 1 & $31.48^{*}$ & $38.47^{*}$ & $74.99^{* *}$ & $20.62^{*}$ & $6.86 \mathrm{~ns}$ & $19.29^{* *}$ \\
\hline Rep within experiment & 6 & 11.95 & 32.16 & 18.08 & 23.97 & 8.63 & 0.0 \\
\hline Soil (S) & 1 & $28.88^{* *}$ & $18.60^{* *}$ & $0.49 \mathrm{~ns}$ & $11.09^{* *}$ & $0.06 \mathrm{~ns}$ & $100.19^{* *}$ \\
\hline Trichoderma harzianum $(\mathrm{T})$ & 1 & $50.60^{*}$ & $80.75^{* *}$ & $233.91^{* *}$ & $23.46^{* *}$ & $8.53^{*}$ & $0.09^{* *}$ \\
\hline$E \times S$ & 1 & $4.86 \mathrm{~ns}$ & $31.67 \mathrm{~ns}$ & $94.73^{*}$ & $13.78 \mathrm{~ns}$ & $3.07 \mathrm{~ns}$ & $15.34^{*}$ \\
\hline $\mathrm{E} \times \mathrm{T}$ & 1 & $0.0 \mathrm{~ns}$ & $21.95^{*}$ & $67.04^{*}$ & $14.56^{*}$ & $3.68 \mathrm{~ns}$ & $0.19^{*}$ \\
\hline $\mathrm{S} \times \mathrm{T}$ & 1 & $0.0 \mathrm{~ns}$ & $4.42^{*}$ & $0.0 \mathrm{~ns}$ & $3.04^{*}$ & $0.0 \mathrm{~ns}$ & $0.13^{*}$ \\
\hline $\mathrm{E} \times \mathrm{S} \times \mathrm{T}$ & 1 & $0.0 \mathrm{~ns}$ & $0.0 \mathrm{~ns}$ & $0.0 \mathrm{~ns}$ & $0.0 \mathrm{~ns}$ & $0.28 \mathrm{~ns}$ & $0.06^{*}$ \\
\hline Pooled error & 25 & 15.91 & 58.94 & 0.99 & 70.30 & 0.47 & 0.03 \\
\hline $\mathrm{CV}[\%]$ & 28 & 3.05 & 14.73 & 8.86 & 7.85 & 36.64 & 7.42 \\
\hline
\end{tabular}

${ }^{*},{ }^{* *}$ and $\mathrm{ns}-$ significant at $\mathrm{p}=0.05, \mathrm{p}=0.01$ and non-significant probability levels, respectively; CV - coefficient of variation 
Table 5. Effect of Trichoderma isolates on several growth parameters of soybean plants

\begin{tabular}{|c|c|c|c|c|c|c|}
\hline \multirow{2}{*}{ Treatments } & \multirow{2}{*}{$\begin{array}{l}\text { Stem height } \\
{[\mathrm{cm}]}\end{array}$} & \multicolumn{2}{|c|}{$\begin{array}{l}\text { Roots weight } \\
{\left[\mathrm{g} \cdot \text { plant }^{-1}\right]}\end{array}$} & \multicolumn{2}{|c|}{$\begin{array}{l}\text { Shoots weight } \\
{\left[\mathrm{g} \cdot \text { plant }^{-1}\right]}\end{array}$} & \multirow{2}{*}{$\begin{array}{l}\text { Disease } \\
\text { severity }\end{array}$} \\
\hline & & fresh & dry & fresh & dry & \\
\hline A & 33.48 a & $4.61 \mathrm{ab}$ & $0.60 \mathrm{~b}$ & $13.47 \mathrm{a}$ & $0.45 \mathrm{a}$ & $0 \mathrm{j}$ \\
\hline $\mathrm{N}$ & $30.72 \mathrm{~b}$ & $4.65 \mathrm{ab}$ & $0.61 \mathrm{~b}$ & $11.39 \mathrm{~b}$ & $0.39 \mathrm{ab}$ & $0 \mathrm{j}$ \\
\hline $\mathrm{AM}$ & $19.03 \mathrm{~h}$ & $1.02 \mathrm{e}$ & $0.05 \mathrm{~d}$ & $5.21 \mathrm{e}$ & $0.05 \mathrm{~d}$ & $0.55 \mathrm{a}$ \\
\hline $\mathrm{NM}$ & $21.69 \mathrm{~g}$ & $1.11 \mathrm{~d} \mathrm{e}$ & $0.06 \mathrm{~d}$ & $7.88 \mathrm{~d}$ & $0.08 \mathrm{~cd}$ & $0.45 b$ \\
\hline AMOT14 & $27.95 \mathrm{~cd}$ & $4.86 \mathrm{a}$ & $0.78 \mathrm{a}$ & $9.45 \mathrm{~cd}$ & $0.29 \mathrm{abc}$ & $0.21 \mathrm{~g}$ \\
\hline AMOT7 & $29.47 \mathrm{bc}$ & $4.93 \mathrm{a}$ & $0.79 \mathrm{a}$ & $11.06 \mathrm{bc}$ & $0.37 \mathrm{ab}$ & $0.19 \mathrm{~h}$ \\
\hline AMET14 & $26.07 \mathrm{de}$ & $3.07 \mathrm{c}$ & $0.48 \mathrm{bc}$ & $8.36 \mathrm{~d}$ & $0.22 \mathrm{bcd}$ & $0.19 \mathrm{~h}$ \\
\hline AMET7 & $25.64 \mathrm{ef}$ & $3.22 b c$ & $0.51 \mathrm{bc}$ & $8.49 \mathrm{~d}$ & $0.20 \mathrm{bcd}$ & $0.17 \mathrm{i}$ \\
\hline NMOT14 & $23.77 \mathrm{f}$ & 2.49 cde & $0.39 c$ & $8.00 \mathrm{~d}$ & $0.17 \mathrm{bcd}$ & $0.28 \mathrm{c}$ \\
\hline NMOT7 & 24.82 ef & $2.66 \mathrm{~cd}$ & $0.42 \mathrm{c}$ & $8.30 \mathrm{~d}$ & $0.20 \mathrm{bcd}$ & $0.24 \mathrm{e}$ \\
\hline NMET14 & $25.61 \mathrm{ef}$ & 2.33 cde & $0.36 \mathrm{c}$ & $8.21 \mathrm{~d}$ & $0.19 \mathrm{bcd}$ & $0.25 \mathrm{~d}$ \\
\hline NMET7 & $26.45 \mathrm{de}$ & 2.50 cde & $0.40 \mathrm{c}$ & $8.14 \mathrm{~d}$ & $0.19 \mathrm{bcd}$ & $0.22 \mathrm{f}$ \\
\hline
\end{tabular}

Each treatment was replicated four times. The experiment was repeated three times with similar results: A - autoclaved soil; $\mathrm{N}-$ non-autoclaved soil; AM - autoclaved soil + M. phaseolina; NM - non-autoclaved soil + M. phaseolina; AMOT14 - autoclaved soil + M. phaseolina + soil treatment with T. harzianum T14; AMOT7 - autoclaved soil + M. phaseolina + soil treatment with T. harzianum T7; AMET14 - autoclaved soil + M. phaseolina + seed treatment with T. harzianum T14; AMET7 - autoclaved soil + M. phaseolina + seed treatment with T. harzianum T7; NMOT14 - non-autoclaved soil + M. phaseolina + soil treatment with T. harzianum T14; NMOT7 - non-autoclaved soil + M. phaseolina + soil treatment with T. harzianum T7; NMET14 - non-autoclaved soil + M. phaseolina + seed treatment with T. harzianum T14; NMET7 - non-autoclaved soil + M. phaseolina + seed treatment with T. harzianum T7. The means with the same letter do not have significant difference according to Tukey's multiple range tests at $\mathrm{p}<0.05$

\section{POX activity}

At all time points investigated except 1 day post-inoculation (dpi), the POX activity increased in soybean roots (compared to healthy plants as the control) due to the T. harzianum treatments. Also, inoculating the pathogen leads to an increase in the enzyme activity at these time points (Fig. 1). Analysis of variance revealed significant differences among the POX activity of plants with various treatments. Enzyme activity in all treatments reached a maximum level at $3 \mathrm{dpi}$, and decreased afterward. The highest levels of POX activity were observed in MT7, MT14, T7, and T14 treatments at 3 dpi, which were not significantly different from each other (Fig. 1).

\section{Total phenolic contents}

Plants have an almost unlimited ability to synthesise aromatic substances, most of which are phenolics or their oxygen-substituted derivatives. In many cases, these substances are involved in plant immunity against pathogens. Our data revealed significant difference in the phenolic contents of various treatments used in this study (Fig. 2). The accumulation of phenolics considerably increased after the soybean seedlings were inoculated with the pathogen, when compared to non-inoculated controls. Also, significantly higher phenolic contents were observed in the treatments with T. harzianum isolates.

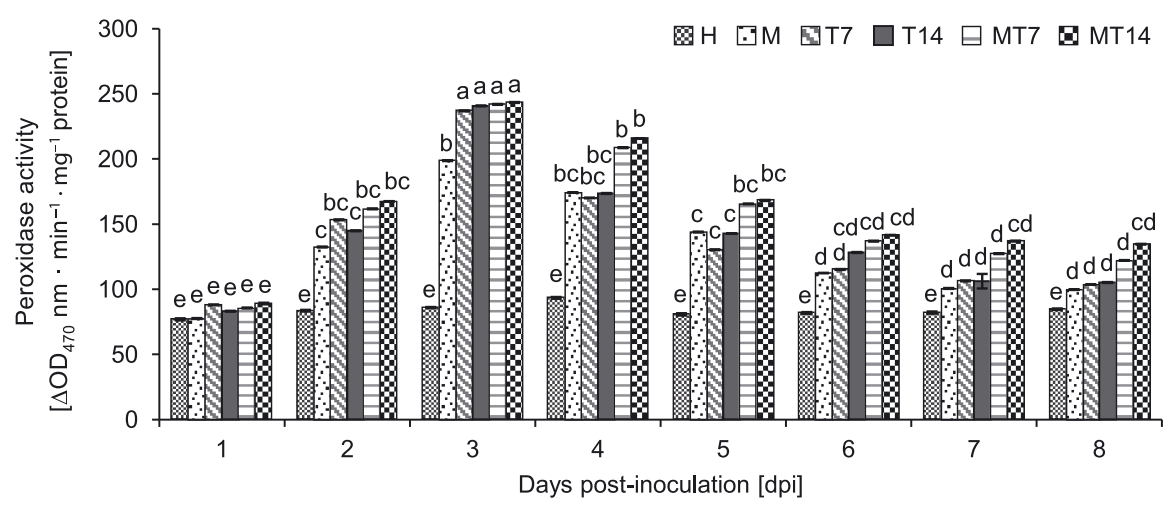

Fig. 1. Peroxidase activity of soybean roots in the presence or absence of Trichoderma harzianum isolates and Macrophomina phaseolina inoculation: $\mathrm{H}$ - healthy plants; $\mathrm{M}$ - plants inoculated with M. phaseolina; T14 - plants inoculated with T. harzianum T14; T7 - plants inoculated with T. harzianum T7; MT14 - plants inoculated with T. harzianum T14 and M. phaseolina; MT7 - plants inoculated with T. harzianum T7 and M. phaseolina. The activity of peroxidase was presented as $\Delta \mathrm{OD}_{470} \mathrm{~nm} \cdot \mathrm{min}^{-1} \cdot \mathrm{mg}^{-1}$ protein. The means with the same letter do not have significant difference according to Tukey's multiple range tests at $\mathrm{p}<0.05$ 


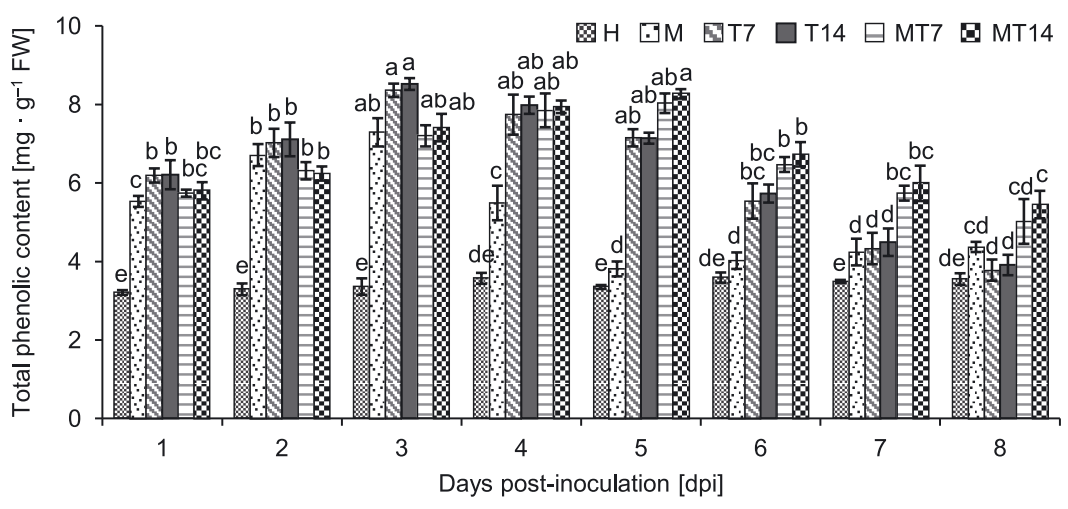

Fig. 2. Total phenolics of soybean root tissues in the presence or absence of Trichoderma harzianum isolates and Macrophomina phaseolina: H - healthy plants; M - plants inoculated with M. phaseolina; T14 - plants inoculated with T. harzianum T14; T7 - plants inoculated with T. harzianum T7; MT14 - plants inoculated with T. harzianum T14 and M. phaseolina; MT7 - plants inoculated with T. harzianum T7 and M. phaseolina. Total phenolics of the roots were expressed as $\mathrm{mg}$ caffeic acid $\cdot \mathrm{g}^{-1}$ of root fresh weight (FW). The means with the same letter do not have significant difference according to Tukey's multiple range tests at $\mathrm{p}<0.05$

At 1, 2, 3, and 4 dpi, in the treatments with T. harzianum and M. phaseolina (i.e. MT7 and MT14), the phenolics levels slightly decreased, when compared to the phenolics detected in treatments with T. harzianum isolates alone. Whereas, at the next time points investigated $(5,6,7$, and 8 dpi) a slight increase in the phenolics of the MT7 and MT14 treatments was observed, when compared to that of the treatments with T. harzianum isolates alone. At 4, 5 , and $6 \mathrm{dpi}$, phenolics levels were significantly higher in all treatments in which T. harzianum was isolated, than that of the plants only inoculated by the pathogen (Fig. 2). At all the investigated time points, the lowest level of phenolics was detected in the control which consisted of healthy plants.

\section{Discussion}

In the present study, the biocontrol capability of various isolates of T. harzianum and T. viride against M. phaseolina, the causual agent of soybean charcoal rot, was investigated using in vitro and in vivo assays. Furthermore, the effect of the most antagonistic isolates (T. harzianum isolates T7 and T14) in priming POX activity and phenolic accumulations in soybean roots were determined. The obtained data revealed that all T. harzianum and T. viride isolates used in this study had a considerable antagonistic effect on mycelial growth of M. phaseolina in dual cultures, when compared to the controls. Out of all the tested Trichoderma isolates, the isolates T7 and T14 showed a maximum inhibition against mycelial growth of the pathogen. Numerous reports indicated that Trichoderma spp. isolates (Ehteshamul et al. 1990; Ehteshamul and Ghaffar 1992) are effective biocontrol agents, and these indications support our results. According to Hermosa et al. (2000), T. harzianum had potential biocontrol activity in dual culture studies against various phytopathogenic fungi such as Phoma betae, Rosellinia necatrix, Botrytis cinerea, and Fusarium oxyporum f. sp. dianthi. It was reported by Asran-Amal et al. (2010), that in vitro screening of five isolates of T. harzianum, one isolate of
Chaetomium globosum, and one isolate of Conetherium mentance, revealed that all of them significantly reduced the growth area of M. phaseolina, Fusarium solani, and Rhizoctonia solani. The higher antagonistic effect of T. harzianum against $M$. phaseolina compared to T. viride was previously observed by Sreedevi et al. (2011). This finding is in agreement with our results on the potent antagonistic activity of T. harzianum isolates T7 and T 14 against $M$. phaseolina, (from among all Trichoderma isolates tested). This antagonistic nature might be due to antibiosis, nutrient competition, and/or cell wall degrading enzymes (Kumar 2013).

To determine the mechanisms involved in microbial antagonism, we tested T. harzianum isolates T7 and T 14 for their capability to produce volatile and non-volatile compounds that inhibit the pathogen growth in vitro. From our results, it is evident that volatile compounds of both T. harzianum isolates decreased the mycelial growth of M. phaseolina. A large variety of volatile secondary metabolites could be produced by Trichoderma spp. such as ethylene, hydrogen cyanide, aldehydes, and ketones, which play an important role in controlling various plant pathogens (Vey et al. 2001). The non-volatile secondary metabolites of $T$. harzianum isolates used in this assay were found to be more effective in suppressing the mycelial growth of M. phaseolina when compared to volatile compounds. Similar to this finding, Tapwal and associates (2011) reported that non-volatile metabolites of T. viride were more effective against $R$. solani, Curvularia lunata, and Alternaria solani. Whereas, volatile compounds of this biocontrol agent were found to be more effective against F. oxysporum (Tapwal et al. 2011). The potential of Trichoderma spp. to produce many volatile (e.g. pyrones, sesquiterpenes) and non-volatile secondary metabolites (e.g. terpenes) has been reviewed by Reino et al. (2008). However, our research in the first to compare the effect of volatile and non-volatile compounds produced by T. harzianum against $M$. phaseolina.

The evaluation of the interaction among soybean plants, M. phaseolina and T. harzianum isolates revealed 
that both T. harzianum isolates reduced charcoal rot disease and promoted plant growth in the greenhouse. Disease severity was lower in the seed treatment in autoclaved soil compared to other treatments. Similar to our results, seed treatment with $T$. harzianum and T. viride was more effective in controlling $R$. solani in Phaseolus vulgaris under both greenhouse and field conditions (Prashanthi et al. 1997). These results indicated that introducing Trichoderma spp. was effective for the success of these isolates in plant growth promotion and for reducing disease severity.

Soil treatment with T. harzianum seems to be more effective for promoting plant growth parameters. Whereas, the seed treatment was more effective for suppressing disease progress compared to the soil treatment in both autoclaved and non-autoclaved soils. The stem height and shoot weight were higher in plants cultivated in autoclaved soil when compared to plants cultivated in non-autoclaved soil. This is in accordance with the observations of Al-Khaliel (2010) on peanut plants which showed reduced growth in non-autoclaved soil despite the fact that they were healthy. Reduced growth in nonautoclaved soil may be due to the presence of lower levels of nutrients available or indigenous microbes that may have negative effects on the plant growth.

The effect that T. harzianum isolates have on enhancing growth parameters in the plants inoculated by the pathogen and the effect the isolates have on the reduction of disease severity were higher in autoclaved compared to non-autoclaved soil. This phenomenon might be due to the better ability of T. harzianum isolates in colonising rhizosphere with the consequent better effect on plant growth and disease control in autoclaved soil because of the absence of other microorganisms (Harman and Kubicek 1998).

The current study revealed that antagonistic T. harzianum isolates were capable of inducing defense responses in soybean plants against M. phaseolina. Total phenolics and POX activity increased in response to inoculation with M. phaseolina, or soybean seeds treated with T. harzianum T7 or T14 isolates alone. Furthermore, seed treatment using $T$. harzianum isolates together with inoculation of the plants by M. phaseolina primed these defense responses in soybean. It is known that the presence of phenolic compounds in plants and their synthesis in response to infection, is associated with resistance (Taheri and Tarighi 2011; Nikraftar et al. 2013). Induced accumulation of phenolics into the cell wall in a SA-dependent way (Alonso-Ramirez et al. 2014) and also by releasing anti-microbial compounds, which leads to the resistance response (Taheri and Tarighi 2010). Phenolic compounds and flavonoids are two kinds of metabolites of phenylpropanoid pathway in plants (Cao et al. 2005). Phenolics are oxidised by peroxidases to form more toxic compounds, known as quinines. It is the quinines which are directly toxic to fungal pathogens (Gogoi et al. 2001).

The present data also revealed a significant increase in POX activity of all treatments having T. harzianum isolates compared to the healthy and the diseased (M. phaseolina infected) control plants. Peroxidase is a useful marker of plant development, physiology, infection and defense
(Zhang and Kirkham 1994). The induction and accumulation of peroxidases is often correlated with the onset of induced resistance, suggesting an active role for these enzymes in defense against pathogenic fungi (Sticher et al. 1997; Van Loon et al. 1998). Similar to our results, enhanced peroxidase activity during plant-fungus interactions have been previously reported by several researchers (Heath 1996). Vidhyasekaran (1997) demonstrated that the POX activity was more in the plants over infection by the pathogens in some plants and it has great role in inhibit the pathogen development. On the other hand, POX catalyses the condensation of phenolic compounds into lignin which is associated with disease resistance in plants and increases in host plants following pathogen infection (Scott-Craig et al. 1995). Peroxidase may be rapidly involved in the peroxidation of substrate molecules, leading to the accumulation of highly toxic compounds (i.e. phenolics), which may contribute to plant defense via their antifungal potential (Ward 1986). However, these compounds may, to some extent, be toxic to the plant itself, and it seems reasonable to assume that mechanisms designed to limit POX expression are activated during the resistance process in order to keep phenolic compounds below the phytotoxic levels. So, the decrease in POX activity observed at $4 \mathrm{dpi}$, and afterward observed in this research, may reflect a process by the plant to protect itself until such activity is needed, such as upon pathogenic attack. Similar findings about the increase in POX activity after the application of biocontrol agents have been reported in different crops (Oostendorp et al. 2001).

Guleria and Kumar (2006) reported a higher activity of POX and increased levels of phenolics in sesame (S. indicum) leaves treated with a leaf extract of neem (Azadirachta indica A. Juss.) and inoculated with Alternaria, the casual agent of leaf spot. It is suggested that neem leaf extract induced POX activity in sesame leaves, which resulted in increased biosynthesis and metabolism of phenolics. Increased phenolic accumulations have been demonstrated to be involved in protecting sesame plants against from Alternaria sesame (Guleria and Kumar 2006). We obtained similar results on priming POX activity upstream of phenolic accumulations by T. harzianum isolates in the soybean-M. phaseolina pathosystem which might be involved in disease suppression by the biocontrol agents.

\section{Conclusions}

The present study demonstrated that two isolates of T. harzianum (T7 and T14) had the potential, as biocontrol agents, to control soybean charcoal root rot caused by M. phaseolina. This is the first report on the higher effect of non-volatile metabolites produced by T. harzianum isolates compared to their volatiles against this necrotrophic pathogen. Also, we demonstrated for the first time, the capability of these biocontrol agents in priming plant defense responses such as POX activity and phenolics accumulation. Future cellular and molecular investigations on resistance responses activated by Trichoderma spp. or other plant growth promoting fungi against various pathogens, will not only improve our knowledge on the mechanisms involved in biological induction of immu- 
nity but would also be useful in developing novel and environmentally safe strategies to control economically important soybean diseases.

\section{Acknowledgements}

We wish to thank Ferdowsi University of Mashhad, Iran, for providing the financial support for this research.

\section{References}

Adekunle A.T., Cardwell K.F., Florini D.A., Ikotun T. 2001. Seed treatment with Trichoderma species for control of dampingoff of cowpea caused by Macrophomina phaseolina. Biocontrol Science and Technology 11 (4): 449-457.

Alonso-Ramírez A., Poveda J., Martín J.I., Hermosa R., Monte E., Nicolás C. 2014. Salicylic acid prevents Trichoderma harzianum from entering the vascular system of the roots. Molecular Plant Pathology 15 (8): 823-831.

Al-Khaliel A.S. 2010. Effect of salinity stress on mycorrhizal association and growth response of peanut infected by Glomus mosseae. Plant, Soil and Environment 56: 318-324.

Aly A.A., Abdel-Sattar M.A., Omar M.R., Abd-Elsalam K.A. 2007. Differential antagonism of Trichoderma sp. against Macrophomina phaseolina. Journal of Plant Protection Research 47 (2): 91-102.

Asran-Amal A., Moustafa-Mahmoud S.M., Sabet K.K., El Banna O.H. 2010. In vitro antagonism of cotton seedlings fungi and characterization of chitinase isozyme activities in Trichoderma harzianum. Saudi Journal of Biological Sciences 17 (2): 153-157.

Babu B.K., Saxena A.K., Srivastava A.K., Arora D.K. 2007. Identification and detection of Macrophomina phaseolina by using species-specific oligonucleotide primers and probe. Мycologia 99 (6): 797-803.

Bai Z., Jin B., Li Y., Chen J., Li Z. 2008. Utilization of winery wastes for Trichoderma viride biocontrol agent production by solid state fermentation. Journal of Environmental Sciences 20: 353-358.

Benitez T., Rincon A.M., Limon M.C., Condon A.C. 2004. Biocontrol mechanisms of Trichoderma strains. International Microbiology 7 (4): 249-260.

Bowen C.R., Schapaugh Jr, W.T. 1989. Relationships among charcoal rot infection, yield, and stability estimates in soybean blends. Crop Science 29 (1): 42-46.

Bradford M.M. 1976. A rapid and sensitive method for the quantitation of microgram quantities of protein utilizing the principle of protein-dye binding. Analytical Biochemistry 72 (1-2): 248-254.

Brotman Y., Landau U., Cuadros-Inostroza A., Takayuki T., Fernie A.R., Chet I., Viterbo A., Willmitzer L. 2013. Trichoderma-plant root colonization: escaping early plant defense responses and activation of the antioxidant machinery for saline stress tolerance. PLoS Pathogens 9 (4), DOI: 10.1371/ journal.ppat.1003221

Cao J., Jiang W., He H. 2005. Induced resistance in Yali pear (Pyrus bretschneideri Rehd.) fruit against infection by Penicillium expansum by postharvest infiltration of acibenzolarS-methyl. Journal of Phytopathology 153 (11-12): 640-646.

Dennis C., Webster J. 1971a. Antagonistic properties of species groups of Trichoderma II. Production of volatile antibiot- ics. Transactions of the British Mycological Society 57 (1): $41-48$.

Dennis C., Webster J. 1971b. Antagonistic properties of species groups of Trichoderma I, production of non-volatile antibiotics. Transactions of the British Mycological Society 57 (1): 25-39.

Ehteshamul H.S., Ghaffar A., Zaki M.J. 1990. Biological control of root rot diseases of okra, sunflower, soybean, and mungbean. Pakistan Journal of Botany 22 (2): 121-124.

Ehteshamul H.S., Ghaffar A. 1992. Efficacy of Trichoderma spp., and Rhizobium meliloti in the control of root rot of fenugreek. Pakistan Journal of Botany 24 (2): 217-221.

Elad Y., Zvieli Y., Chet I. 1986. Biological control of Macrophomina phaseolina (Tassi) Goid by Trichoderma harzianum. Crop Protection 5 (4): 288-292.

Etebarian H.R. 2006. Evaluation of Trichoderma isolates for biological control of charcoal stem rot in melon caused by Macrophomina phaseolina. Journal of Agricultural Science Technology 8 (3): 243-250.

Fernandez R.B., De Santiago A., Delgado S.H., Perez N.M. 2006. Characterization of Mexican and non-Mexican isolates of Macrophomina phaseolina based on morphological characteristics, pathogenicity on bean seeds and endoglucanase genes. Journal of Plant Pathology 88 (1): 1-8.

Gary F.A., Mihail J.D., Lavigne R.J., Porter P.M. 1991. Incidence of charcoal rot of sorghum and soil populations of Macrophomina phaseolina associated with sorghum and native vegetation in Somalia. Mycopathologia 114: 145-151.

Gogoi R., Singh D.V., Sivastava K.D. 2001. Phenols as a biochemical basis of resistance in wheat against Karnal bunt. Plant Pathology 50 (4): 470-476.

Guleria S., Kumar A. 2006. Azadirachta indica leaf extract induces resistance in sesame against Alternaria leaf spot diseases. Journal of Cell Molecular Biology 5 (2): 81-86.

Harman G.E. 2006. Overview of mechanisms and uses of Trichoderma spp. Phytopathology 96 (2): 190-194.

Harman G.E., Kubicek C.P. 1998. Trichoderma and Gliocladium, Enzymes, Biological Control and Commercial Applications. Vol. 2. Taylor \& Francis, London, UK, 393 pp.

Heath M.C. 1996. Plant resistance to fungi. Canadian Journal of Plant Pathology 18: 469-475.

Hermosa R., Viterbo A., Chet I., Monte E. 2012. Plant-beneficial effects of Trichoderma and of its genes. Microbiology 158 (1): $17-25$.

Hermosa M.R., Grondona I., Iturriaga E.A., Diaz-Minguez J.M., Casytro C., Monte E. Garcia-Acha I. 2000. Molecular characterization and identification of biocontrol isolates of Trichoderma spp. Applied and Environmental Microbiology 66 (5): 1890-1898.

Herridge D.F., Peoples M.B., Boddey R.M. 2008. Global inputs of biological nitrogen fixation in agricultural systems. Plant Soil 311 (1): 1-18.

Kehri H.K., Chandra S. 1991. Antagonism of Trichoderma viride to Macrophomina phaseolina and its application in the control of dry root rot of mung. Indian Phytopathology 44 (1): 60-63.

Khan S.N. 2007. Macrophomina phaseolina as causal agent for charcoal rot of sunflower. Mycopathologia 5: 111-118.

Koenning S.R., Wrather J.A. 2010. Suppression of soybean yield potential in the continental United States by plant diseases 
from 2006 to 2009. Online. Plant Health Progress. DOI: 10.1094/PHP-2010-1122-01-RS.

Kubicek C.P., Mach R.L., Peterbauer C.K., Lorito Kubicek M. 2001. Trichoderma: from genes to biocontrol. Journal of Plant Pathology 83 (2): 11-23.

Kumar S. 2013. Trichoderma: a biological control weapon for managing plant diseases and promoting sustainability. International Journal of Agricultural Sciences and Veterinary Medicine 1 (3): 106-121.

Lorito M., Woo S.L., Harman G.E., Monte E. 2010. Translational research on Trichoderma: from 'omics to the field. Annual Review of Phytopathology 48: 395-417.

Malmierca M.G., Cardoza R.E., Alexander N.J., McCormick S.P., Hermosa R., Monte E., Gutiérrez S. 2012. Involvement of Trichoderma trichothecenes in the biocontrol activity and induction of plant defense-related genes. Applied and Environmental Microbiology 78 (14): 4856-4868.

Mengistu A., Ray J.D., Smith J.R., Paris R.L. 2007. Charcoal rot disease assessment of soybean genotypes using a colonyforming unit index. Crop Science 47: 2453-2461.

Nerey Y., Van Beneden S., Franca S., Jimenez A. 2010. Influence of soil type and indigenous pathogenic fungi on bean hypocotyls rot caused by Rhizoctonia solani AG4 HGI in Cuba. Soil Biology and Biochemistry 42 (5): 797-803.

Nikraftar F., Taheri P., Falahati Rastegar M., Tarighi S. 2013. Tomato partial resistance to Rhizoctonia solani involves antioxidative defense mechanisms. Physiological and Molecular Plant Pathology 81 (1): 74-83.

Oostendorp M., Kunz W., Dietrich B., Staub T. 2001. Induced resistance in plants by chemicals. European Journal of Plant Pathology 107 (1): 19-28.

Pearson C.A.S., Schwenk F.W., Crowe F.J., Kelly K. 1984. Colonization of soybean roots by Macrophomina phaseolina. Plant Disease 68 (12): 1086-1088.

Persson L., Bodker L., Larsson-Wikstrom M. 1997. Prevalence and pathogenicity of foot and root rot pathogens of pea in Southern Scandinavia. Plant Disease 81 (2): 171-174.

Prashanthi S.K., Sreekanth K., Sreenivasa M.N., Kulkarni S. 1997. Integrated management of root rot disease of Phaseolus vulgaris caused by Rhizoctonia solani. Environmental Ecology 15: 800-802.

Prévost D., Bertrand A., Juge C., Chalifour F.P. 2010. Elevated $\mathrm{CO}_{2}$ induces differences in nodulation of soybean depending on bradyrhizobial strain and method of inoculation. Plant Soil 331 (1): 115-127.

Rayatpanah S., Nanagulyan S.G., Alav S.V., Razavi M., Ghanbari-Malidarreh A. 2011. Pathogenic and genetic diversity among Iranian isolates of Macrophomina phaseolina. Chilean Journal of Agricultural Research 72: 40-44.

Reino J.L., Guerriero R.F., Hernàndez-Galà R., Collado I.G. 2008. Secondary metabolites from species of the biocontrol agent Trichoderma. Phytochemistry Reviews 7 (1): 89-123.

Purkayastha S., Kaur B., Dilbaghi N., Chaudhury A. 2006. Characterization of Macrophomina phaseolina, the charcoal rot pathogen of cluster bean, using conventional techniques and PCR-based molecular markers. Plant Pathology 55 (1): 106-116.

Salik N.K. 2007. Macrophomina phaseolina as causal agent for charcoal rot of sunflower. Mycopath 5 (2): 111-118.

Savazzini F., Longa C.M.O., Pertot I. 2009. Impact of the biocontrol agent Trichoderma atroviride SC1 on soil microbial com- munities of a vineyard in northern Italy. Soil Biology and Biochemistry 41: 1457-1465.

Scott-Craig J.S., Kerby K.B., Stein B.D., Sommerville C.S. 1995. Expression of an extracellular peroxidase that is induced in barley (Hordeum vulgare) by the powdery mildew pathogen (Erysiphe graminis f. sp. hordei). Physiological and Molecular Plant Pathology 47 (6): 407-418.

Seevers P.M., Daly J.M. 1970. Studies on wheat stem rust resistance control at sr6 locus, I. The role of phenolic compounds. Phytopathology 6: 1322-1328.

Shali A., Ghasemi S., Ahmadian G., Ranjbar G., Dehestani A., Khalesi N., Motallebi E., Vahed M. 2010. Bacillus pumilus SG2 chitinases induced and regulated by chitin, show inhibitory activity against Fusarium graminearum and Bipolaris sorokiniana. Phytoparasitica 38 (2): 141-147.

Singh T., Saikia R., Jana T., Arora D.K. 2004. Hydrophobicity and surface electrostatic charge of conidia of the mycoparasitic Trichoderma species. Mycological Progress 3 (3): 219-228.

Singh N., Pandey P., Dubey R.C., Maheshwari D.K. 2008. Biological control of root rot fungus Macrophomina phaseolina and growth enhancement of Pinus roxburghii (Sarg.) by rhizosphere competent Bacillus subtilis BN1. World Journal of Microbiology and Biotechnology 24: 1669-1679.

Sreedevi B., Charitha Devi M., Saigopal D.V.R. 2011. Isolation and screening of effective Trichoderma spp. against the root rot pathogen Macrophomina phaseolina. Journal of Agricultural Technology 7 (3): 623-635.

Sticher L., Mauch-Mani B., Metraux J.P. 1997. Systemic acquired resistance. Annual Review of Phytopathology 35: 235-270.

Su G., Suh S.O., Schneider R.W., Russin J.S. 2001. Host specialization in the charcoal rot fungus, Macrophomina phaseolina. Phytopathology 91 (2): 120-126.

Taheri P., Tarighi S. 2010. Riboflavin induces resistance in rice against Rhizoctonia solani via jasmonate-mediated priming of phenylpropanoid pathway. Journal of Plant Physiology 167 (3): 201-208.

Taheri P., Tarighi S. 2011. A survey on basal resistance and riboflavin-induced defense responses of sugar beet against Rhizoctonia solani. Journal of Plant Physiology 168 (10): 1114-1122.

Taliei T., Safaei N., Aghajani M.A. 2012. Survival of Macrophomina phaseolina and associated mycobiota on soybean residuals and the effect of Trichoderma harzianum on their population dynamics. Journal of Applied Researches in Plant Protection 1: 1-13.

Tapwal A., Singh U., Teixeira de Silva J.A., Singh G., Grag S., Kumar R. 2011. In vitro antagonism of T. viride against five phytopathogens. Pest Technology 5 (1): 59-62.

Thilagavathi R., Saravanakumar D., Ragupathi N., Samiyappan R. 2007. A combination of biocontrol agents improves the management of dry root rot (Macrophomina phaseolina) in greengram. Phytopathologia Mediterranea 46: 157-167.

Todd T.C. 1993. Soybean planting date and maturity effects on Heterodera glycines and Macrophomina phaseolina in southeastern Kansas. The Journal of Nematology 25 (4S): 731737.

Van Loon L.C., Bakker P.A.H.M., Pieterse M.J. 1998. Systemic resistance induced by rhizosphere bacteria. Annual Review of Phytopathology 36: 453-483.

Vasebi Y., Safaie N., Alizadeh A. 2013. Biological control of soybean charcoal root rot disease using bacterial and fungal 
antagonists in vitro and greenhouse condition. Journal of Crop Protection 2: 139-150.

Verma M., Brar S.K., Tyagi R.D., Sahai V., Prévost D., Valéro J.R., Surampalli R.Y. 2007. Bench-scale fermentation of Trichoderma viride on wastewater sludge: rheology, lytic enzymes and biocontrol activity. Enzyme and Microbial Technology 41 (6): 764-771.

Vey A., Hoagland R.E., Butt T.M. 2001. Toxic metabolites of fungal biocontrol agents. p. 311-346. In: "Fungi as Biocontrol Agents: Progress, Problems and Potential" (T.M. Butt, C. Jackson, N. Magan, eds.). CAB International, Bristol, UK, 390 pp.

Vidhyasekaran P., Rabindran R., Muthamilan M., Nayar K., Rajappan K., Subramanian N., Vasumathi M. 1997. Develop- ment of a powder formulation of Pseudomonas fluorescens for control of rice blast. Plant Pathology 46 (3): 291-297.

Ward E.W.B. 1986. Biochemical mechanisms involved in resistance of plants of fungi. p. 107-131. In: "Biology and Molecular Biology of Plant Pathogen Interactions" (J.A. Butt Baily, ed.). Spinger-Verlag KG., Berlin, Germany, 415 pp.

Zhang J., Kirkham M.B. 1994. Drought-stress-induced changes in activities of superoxide dismutase, catalase, and peroxidase in wheat species. Plant and Cell Physiology 35 (5): 785-791.

Ziedan E.H., Saad M., Farage S. 2005. Biological controls of grapevine root rot by antagonistic microorganism's. African Journal of Mycology and Biotechnology 13 (3): 19-36. 